Julianna FALUDI

\title{
A SHOWROOM TURNED FAB LAB: OPEN COLLABORATIVE INNOVATION IN OPEN KITCHEN DESIGN - A CASE STUDY
}

This paper presents an open table design project introduced by a high-end kitchen producing company in collaboration with maker communities, independent designers and the wider public. The case illustrates a hybrid open/collaborative innovation strategy, strategically adapted by a firm for raising awareness, engaging the public, to raise its design options, and enriching its core design concepts.

Keywords: modularity, open innovation, design table, open collaborative innovation, kitchen production, design-driven industries, digital fabrication

Engaging with the debate on innovation openness this paper illustrates a case of a hybrid form, tempting to go beyond what is measured by studies on a larger scale. The scrutiny given to the case of Kitchen Becomes Open project opens a new perspective for further research where innovation is design-driven, open and experimental. A rising interest in open, user and collaborative innovation is witnessed in scholarship during the past decades, where firstly considerable focus was given to technology-intensive industries. The buzz on open innovation has created many and various meanings, and usage of the notion. What actual openness means has two fundamental approaches in innovation scholarship: one focusing on the (producer) firm, and the other on the outcome of innovation: being a public good or not (scholarship on innovation openness can be grouped into 4 main strands: Faludi, 2014). First, the notion of 'open innovation' derives from Chesbrough's frame (2006): where innovation is interpreted based on the Schumpeterian understanding of 1) producer-driven innovation, thus the firm strategically puts use to its resources and capabilities to innovate. Chesbrough focuses on how firms (can and might and do) draw in external resources to innovate, and also on how the outcome of innovation, and the spillovers of the process (patents, etc.) are being commercialized on. Thus, raising the capacities of the firm for open innovation implies rendering impermeability to it (2). Moreover, investigations on networks and ties over firms benefiting from knowledge-share (Brusoni, 2001; Luo et al., 2012; Malerba, 2005; Simard - West, 2006) are linked to the producer-driven model (3). Shifting the locus of innovation from the producer, one will find at the other end the user (4), who happens to develop solutions not met by firms, and then taken up by the producer at a given stage (benefiting from it). This strand was first theorized by Von Hippel $(1976,1988,2005)$. Digital technology and platforms (often created by firms) called for a further strand investigating the outcome of innovation: where the locus of innovation might be a community of people and the outcome is a public good (4).

By bringing in a systematic approach Baldwin and Von Hippel have drawn on the different possible ways firms might follow (Baldwin - von Hippel, 2011), suggesting the frame of open collaborative innovation to study cases labeled as user-producer co-creation, collaborative innovation. This latter type, innovation driven by collaboration was studied in open source software development (Lee - Cole, 2003; Baldwin Clark, 2006; Dahlander et al., 2008; Harison - Koski, 2010), online games development (Potts et al., 2008), branding cultural projects (Dell'Era, 2010) in fashion and music industry (Huage - Hracs, 2010), or in crowd science (Franzoni - Sauermann, 2014). However, little is known about open collaborative innovation projects resulting in a public good in fields outside open source software development.

To put it bluntly (following Baldwin and Von Hippel's (2011) suggestion), openness refers to the permeability of a firm: thus how external sources are used for innovation, where spillovers and outcomes can be commercialized on (producer-driven), or the public good nature of the outcome of innovation, where collaboration is driven rather by collective action. We also 
know, that companies might create platforms, where modules are set free for contributions where users, collaborators can innovate on (Schilling, 2009; Greenstein, 2009)

Design might take the role of the problem-solver in innovation (Alexander, 1964; Simon, 1969), or the driver contributing to the value creation process of firms (D'Ippolito, 2014), as well as, a mean to coordinate and improve product design development (Ravasi - Stigliani, 2012).

Looking from the angle of design-driven industries, we know that firms often innovate in various collaboration forms (Pisano - Verganti, 2008). For conveying meanings companies might work with a portfolio of designers carefully curated to overarch cultures (Dell'Era - Verganti, 2010), where brands as social constructs are valued by the public based on shared meanings (Arvidsson, 2005). Innovation as value creation in the stylistic, aesthetic or semantic realm is prevalent in the creative industries (Caves, 2000; Cappetta et al., 2006; Cillo - Verona, 2008; Potts et al., 2008; Ravasi - Rindova, 2008, in the fashion industry: Tran, 2010).

Firms in the design-driven industries are pushed to launch novelties on the market framed by events (on the role of awards: Gemser - Wijnberg, 2002). Enterprises are prone to shape the discourse on design through various channels, where the festivalization as e.g. Design Week in Milan plays an important role. Opening up the design process thus invites a larger public to engage in the process itself as well as to enter the wider discourse.

\section{Open Design}

Open design (van Abel et al., 2011) and collaboration makes possible for a community to develop ideas, and products in an additive manner. Once a design is created it is launched open for access and use, where the iteration process is taken by the community either improving it, or developing further solutions, and adaptation to other fields. Furthermore, making things together channels in knowledge and resources, where the value generation process might restructure the production process itself (Benkler, 2006). One important aspect here is that no design, or idea is lost (at least the possibility of being lost is lower) if it enters a community where anyone can take and run with it. The other is that it brings alternatives to the traditional model, where designers present their work to the producer who decides on prototyping, developing and manufacturing of the product. Due to the lowering costs of prototyping with desktop technology (3-D printers, laser-cutters, software) designers can elaborate their projects at a different level. Fab Labs unite communities fabricat- ing and experimenting on a range of solutions to meet their everyday needs or pursue defined goals based on accumulated and shared knowledge, contributing to the advancement of technologies in robotics, electronics, 3-D printing. Makers might share goals (as the The RepRap ${ }^{1}$ movement started from the UK in 2005 developing a 3-D printer to print its own components (de Bruijn, 2011)), and community-driven experimentation fosters overall technological advancement. The philosophy of DIY (do-it-yourself) of experimentation and open iteration at the core of their activity swiftly turns entrepreneurial (Faludi, 2017a).

In sum, open design lies in the realm of open collaborative innovation creating a public good. Again, Schumpeterian understanding considers innovation as that of initiated by the producer, benefiting from the value created. In contrast, open collaborative innovation is driven by innovators rendering their achievements into the public domain, where participants are not rivals, and they do not plan to sell the outcome or related property rights (Baldwin - von Hippel, 2011, p. 1403.). If we consider an enterprise commercializing on the value created by its innovation activity, we are bound to think that openness might imply here the producer-driven legacies, and the Chesbrough (2006) type of permeability of the firm. Specifically, generating solutions by sourcing in external knowledge, commercializing on spillovers, and mining out partnerships in development for entering new markets.

Openness is extensively researched as remaining within the (usual) structures of the net of suppliers or partnerships based on similarity, or close complementarity as seen above. This case in contrast exemplifies that a wilder approach toward reaching out to contributors can bring about connections that wouldn't have been thought of before. Open collaborative innovation where the outcome is a public good, gives floor for experimentation creating a playground for divergent ideas. Reaching out to unusual patterns of open collaborative forms is a challenge for high-end design-driven enterprises.

\section{Method and Research Question}

The Kitchen Becomes Open project was unique in framing the event of Fuori Salone with an open design table project overarching the worlds of digital fabrication, makers and that of post-industrial design of a high-end design-driven firm relying on a supplier network both in terms of production and innovation. This made it a valuable illustration to scrutinize an atypical case, taken from the field (being part of a broader research conducted by the author on open innovation patterns in the design-driven industries, backed by fieldwork 
in Milan, Italy). The case is demonstrated to reveal a process (Siggelkow, 2007), and the analysis strives to look behind the "hows" (Yin, 2003), as atypical cases offer opportunity to learn (Stake, 2003, p. 152.). I chose a single-case approach not for it being representative but to explore a hybrid model to bring evidence in the intersection of theories on open innovation.

The case study relies on data collected during field visits to the factory of Valcucine in Pordenone, the showroom in Milan, and the Fab Lab of DotDotDot, and a set of semi-structured interviews on the project 'Kitchen Becomes Open' with representatives of Valcucine, DotDotDot, and Arduino. Secondary data (available on the web) adds validity to the case (Arksey - Knight, 1999). I used theory-building approach in viewing the data from the scholarly angles of innovation openness. The interviews of the key informants were recorded, while observations noted. As this research focused rather on understanding of viable forms tapped in the field, there was no contrast drawn to this very case for generalizability of results.

The text of the interviews was coded, and systemized. First, I modelled the evolution of design of Valcucine, along the core-design concepts, since the establishment of the company, with a focus on innovation. For interpreting this given case I relied on the theoretic framework developed on understanding innovation openness thus, along the main differences of the two main strands or ends of how openness is interpreted in innovation literature: 1 . from the perspective of permeability of the firm, and 2. how collaboration in an experimental set-up_ends with a public good, or a hybrid public good. The analysis thus focuses on the main features of the two models: the outcome of the innovation (if it is a public good, or not), and the benefits and spillovers. For this I focused on the incentives behind the experimentation ( $R \& D$ phase): as a mere open-ended project, or a well-defined set of activities aiming at developing a product, and on the competition within the project (among the participants: depending on if they are rivals). Transaction costs add to the argument on benefits and costs of innovation at stake. The analysis and data collection, interpretation was structured around the research question of:

What are the benefits and costs of an open design table project for high-end design-driven company applying a hybrid form of open collaborative innovation?

\section{Discussion}

\section{Toward Open Design}

Open innovation serves for advancing technology, a practice adopted by Valcucine over the years was to mine its network of suppliers. Suppliers, however also follow the realm of producer-driven innovation for raising the value of their products and to gain profits. The need for new solutions and advanced technologies, for example to introduce robotics in an unusual manner into the world of food design, or to improve ergonomics in an unprecedented manner was there, along with the need for innovative brand communication.

DotDotDot and Valcucine had run together several projects before, and the experience gained from the world of makers, Fab Labs and open design was at the disposal of DotDotDot, a company merging art, architecture, exhibition design and design, with a decade of experience and a substantial network of partners elaborating multidisciplinary projects with open and participative working methods. The shopping list of the ingredients for Kitchen Becomes Open thus was:

- a modular product as a platform to innovate on, that is a modular kitchen of easy design providing with flexibility and a range of solutions to elaborate on, adaptable to different functions and spaces (Meccanica is a modular kitchen engineered by Valcucine for flexible needs: it is of relatively lower cost to be accessible for larger targets, manufactured in the product line under the brand DeMoDe (stands for Democratic Modern Design). Meccanica exploring the philosophy of degrowth features radical solutions for reducing materials used, being $100 \%$ recyclable and $80 \%$ reusable, featuring no glue (thus no formaldehyde emission), furthermore it can be personalized (featuring wood, metal and textile). Meccanica can be self-constructed, disassembled and then reassembled, modules can be added, or eliminated, and stretched toward living spaces. Due to its mobile construction and modularity Meccanica was already open-ended for user-creation, thus it served as a perfect starting point, a platform for the designer team to innovate on.),

- knowledge and capabilities of makers and Fab Labs,

- discourse on furniture and kitchen design hyped by the event open to the public (Fuori Salone, Milano),

- partnership providing with specialized knowledge, capabilities and visibility, and of course

- openness of the firm toward experimentation with new solutions in both design development, and communication.

\section{Kitchen Becomes Open}

The one-week event of Kitchen Becomes Open was organized during Fuori Salone, the ultimate event tackling experimental design in response to and running 
during Milan Design Week (6-11 April, 2014). Fuori Salone is "a collection of fringe events", an "intellectual life of enterprises" devoting themselves to "research and innovation, rather than sales" (Malossi, 2009). It is a response to the institutionalized Salone del Mobile, the event presenting novelties in furniture design focusing ultimately on interior design, with a spring of discussions and presentations. Salone del Mobile is reserved for the establishment, with pre-booked places for the high-quality producers in the realm of the "classics of design'. In contrast or in addition Outside the Salon (Fuori Salone) is reserved for experimentation outside the "conventional system of communication". In this spirit Kitchen Becomes Open turned the elegant showroom with cutting-edge technology of Valcucine in the posh Brera (Brera Design District) into a Fab Lab for a weeks' time.

“...é stato anche interessante trasformare quello che é il showroom dal Valcucine. Valcucine ha un target abbastanza alto, elegante, abbiamo fatto un Fab Lab dentro al showroom, quindi gente che lavorava, che tagliava, faceva polvere, é stato molto bello..."

"it was interesting to transform the showroom of Valcucine. Valcucine has a high target, it is elegant, while we made a Fab Lab inside the showroom, where people were working, cutting, making dust, it was beautiful..."

(Dotdotdot, curator, 2014)

Electronics, robotics, laser-cutters, 3-D printers, and mechanical tools have entered the showroom along with a curious and wandering public, who could freely contribute to the engineering work of a team of professionals. Open discussions and research moderated by invited academics, architects, professionals ${ }^{2}$ invited to add comments, ideas, views, arguments to the process by all:

"sono stati invitati una serie di mentor professionisti di alto livello nel ambito del design strategico che venivano a parlare con il gruppo di lavoro e apportavano anche loro contributo..." "A range of high level professional mentors were invited from the field of strategic design, who were talking to the working group, and contributed to their work..." (curator)

The team consisted of 12 designers, makers, planners $^{3}$ selected from 110 applications ${ }^{4}$ featuring applicants with a diverse background (designer, architect, engineer/ developer, student). The members of the designer team were hired for this project, thus their con- tribution was paid. The outcome of their work licensed open access for gaining visibility in the long term.

Partnership with Arduino was not less important, being a forerunner in digital fabrication and innovation platform for makers in the digital world. Coming from the nest of Ivrea (former Interaction Design Institute in the traditional place of the famous factory of Olivetti, sponsored by Olivetti and Telecom) Arduino is a tool "designed for makers and companies wanting to make their products easily recognizable" (http://www. arduino.cc/), operating with a global community built around it, representing a valuable source of user innovators in the long run, and a potential customer of the Meccanica, that provides with an interface to work on.

The project was open to the public allowing for participation in the design process for all:

\begin{abstract}
"ovviamente da stare in salone era molto faticoso e le porte erano aperte ai tutti quindi la gente veniva dalla strada."

"it is obvious, that it was very tiring to be in the showroom, the doors were open for all, people were coming in from the streets." (curator)
\end{abstract}

\section{Partnership of the Project}

Figure 1

\begin{tabular}{|l|l|}
\hline $\begin{array}{l}\text { DotDotDot } \\
\text { Developer/ curator of the } \\
\text { project }\end{array}$ & $\begin{array}{l}\text { Collaboration in the imple- } \\
\text { mentation of the project, } \\
\text { joint selection of the team }\end{array}$ \\
\hline $\begin{array}{l}\text { Designers' team } \\
\text { 12 professionals contract- } \\
\text { ed for development of the } \\
\text { design }\end{array}$ & $\begin{array}{l}\text { Selected through an open } \\
\text { call, and contracted for the } \\
\text { week of developing the de- } \\
\text { sign of the new kitchen }\end{array}$ \\
\hline $\begin{array}{l}\text { Invited professionals } \\
\text { Moderating the design pro- } \\
\text { cess, discussions }\end{array}$ & $\begin{array}{l}\text { Contracted for providing } \\
\text { with expertise }\end{array}$ \\
\hline $\begin{array}{l}\text { Arduino } \\
\text { Digital fabrication, robotics }\end{array}$ & $\begin{array}{l}\text { Collaboration where Ardui- } \\
\text { no provided with expertise, } \\
\text { and robotics/ tools as a } \\
\text { sponsor }\end{array}$ \\
\hline $\begin{array}{l}\text { Valcucine (DeMode) } \\
\text { Meccanica } \\
\text { Providing expertise in con- } \\
\text { struction, mechanics }\end{array}$ & $\begin{array}{l}\text { DeMode is a brand of } \\
\text { kitchens designed and engi- } \\
\text { neered by Valcucine. }\end{array}$ \\
\hline $\begin{array}{l}\text { Spotti Srl. } \\
\text { Vendors of Valcucine }\end{array}$ & $\begin{array}{l}\text { Vendors of Valcucine, the } \\
\text { showroom in corso Garibal- } \\
\text { di, Milano which provided } \\
\text { with location is maintained } \\
\text { in collaboration with Val- } \\
\text { cucine }\end{array}$ \\
\hline $\begin{array}{l}\text { Mechanical equipment } \\
\text { suppliers } \\
\text { Sponsors (Bosch, DWS } \\
\text { system, Gravotech) }\end{array}$ & $\begin{array}{l}\text { Collaboration with sponsors } \\
\text { providing the equipment for } \\
\text { the kitchen }\end{array}$ \\
\hline
\end{tabular}


The initiator of the project was a third party, DotDotDot, a firm providing with its expertise in participative and open design methodology. DotDotDot curated the project in close cooperation with Valcucine. Remarkably, DotDotDot was able to answer an internal need of Valcucine "to channel in new resources for innovation for creation of new markets, and to enhance in-house technology" (Chesbrough, 2006) by delivering an open design project ready to implement. Valcucine financed the project as an investment in communication, and a range of sponsors contributed. In this respect it is in the realm of the producer as driver of innovation, however the initiator was a third party, as pointed out above.

The outcomes, thus designs and prototypes of the project were not patented, but rendered open access and licensed under Creative Commons $\mathrm{s}^{5} \mathrm{CC}$ by-nc-sa 4.0 with the permission to distribute, modify and create projects based on the original, except for business purposes, recognizing the author's paternity. The out- come of the project thus, was a public good, where participants were not rivals as did not plan to sell or commercialize the innovation or the related property rights (Baldwin - von Hippel, 2011, p. 1403.). Participants had the same scheme and terms of contract, suppling their individual expertise and knowledge as a team forming a project-based organization in the frame of Kitchen Becomes Open. Since participants delivered their labor to the contractor along with related intellectual property rights the project can be considered a hybrid model of open collaborative innovation. (Figure 1)

\section{From Open Innovation Toward an Open Collaborative Project}

Valcucine is open to incorporate solutions developed by its supplier net (new materials, technology) operating in a just-in-time production system. Suppliers demonstrate their competitiveness obtaining and constantly updating their technology and capabilities, with

\section{Hybrid Model of Open (Collaborative) Innovation}

\begin{tabular}{|c|c|c|c|}
\hline \multicolumn{4}{|c|}{ Hybrid Model of Open (Collaborative) Innovation } \\
\hline Kitchen Becomes Open & $\begin{array}{l}\text { Open Collaborative } \\
\text { Innovation (Baldwin, } \\
\text { von Hippel 2011) }\end{array}$ & Producer-driven (Chesbrough 2006) & Features \\
\hline Yes: licensed under CC 0.4 & $\begin{array}{l}\text { The outcome is a public } \\
\text { good }\end{array}$ & $\begin{array}{l}\text { The producer benefits from the innova- } \\
\text { tion, by profiting or by selling the related } \\
\text { Property Rights }\end{array}$ & $\begin{array}{l}\text { Benefits of } \\
\text { innovation }\end{array}$ \\
\hline $\begin{array}{l}\text { Experimentation with no spe- } \\
\text { cific product constraint }\end{array}$ & $\begin{array}{l}\text { Collaborators contribute } \\
\text { for free to experiment (no } \\
\text { constraint) and create inno- } \\
\text { vation }\end{array}$ & $\begin{array}{l}\text { The producer invests in innovation to } \\
\text { create value, and targets results (some } \\
\text { experimentation exists however) }\end{array}$ & Incentives \\
\hline $\begin{array}{l}\text { Designers were rivals when } \\
\text { applied to the team. No rivalry } \\
\text { in co-creation of design table. }\end{array}$ & Designers are not rivals & Designers of innovation are rivals & Competition \\
\hline $\begin{array}{l}\text { Designers experimented in the } \\
\text { frame of a design table, and } \\
\text { arrived to tangible results. No } \\
\text { specified push, however mo- } \\
\text { netary incentives to produce } \\
\text { results. }\end{array}$ & $\begin{array}{l}\text { Innovation to } 1 \text {. experiment, } \\
\text { 2. to create a specific utility/ } \\
\text { software, etc. }\end{array}$ & Innovation to create value & Value creation \\
\hline $\begin{array}{l}\text { Costs related to experimenta- } \\
\text { tion, transaction costs of colla- } \\
\text { boration }\end{array}$ & $\begin{array}{l}\text { Transaction costs related to } \\
\text { experimentation } \\
\text { Design costs divided among } \\
\text { collaborators, and all benefit } \\
\text { the value }\end{array}$ & $\begin{array}{l}\text { Costs related to innovation and experi- } \\
\text { mentation conforming quality and tech- } \\
\text { nical standards } \\
\text { Design costs born by the producer, } \\
\text { whom benefits of the value }\end{array}$ & Costs \\
\hline $\begin{array}{l}\text { For opening up the design table } \\
\text { to source in knowledge and } \\
\text { expand the market. }\end{array}$ & $\begin{array}{l}\text { Partnerships are based on } \\
\text { collaboration based on a } \\
\text { variety of capabilities }\end{array}$ & $\begin{array}{l}\text { Partnerships are based on sourcing in } \\
\text { knowledge and technology, raise capa- } \\
\text { bilities, and expand the market, and out- } \\
\text { sourcing spillovers of R\&D }\end{array}$ & Partnerships \\
\hline
\end{tabular}


a specialized knowledge in production that is external to the enterprise. In developing and engineering its new products Valcucine follows a semi-open strategy on the palette of open/ semi-open and closed innovation schemes of Barge-Gil' (2010, p. 586-587.): thus "having cooperated or bought external R\&D", where most important external knowledge was as important as its internal knowledge. Internal knowledge of the technical and designer staff of Valcucine served the co-creative experiment to back with technical knowledge on feasibility of suggested solutions, and represented the core design concepts (beauty, functionality, sustainability, ergonomics). While the overall innovation story of Valcucine fits into the Chesbrough-type permeability of the firm (nested into the network of suppliers), this project witnessed a shift toward participative and collaborative forms of experimentation. The Kitchen Becomes Open project (Figure 2) is a hybrid model of open collaborative innovation as the problem is posed by the producer, solutions are solicited from third parties, despite that selected solutions are not closed by the producer to make profit from, but revealed open (as opposed to closed collaborative innovation: coined by Baldwin and von Hippel 2011, and identified by others and termed 'crowd-sourcing'). At the same time the clear intention of the project was to pick from the 'goulash' of good and bad ideas:

\section{"molti di questi progetti avevano l'intenzione di portargli avanti, svilupargli ed eventualmente commercializzare." \\ "many of these projects were considered to be developed on, and finally commercialized on." (curator)}

\section{Costs and Benefits of Kitchen Becomes Open}

Transaction costs of innovation include costs of research and development (iteration, testing). Experimentation and lab conditions of opening up innovation on one hand raise design options channeling in knowledge not available in-house (or within the established supplier-network and partnerships), and raises costs related to coordination of the pool of different expertise and new partnerships, and enforcement of the core-design concepts on the other hand. Open collaboration and the activity of makers is structured around experimentation free in choice of approach, selected tools and methods, while constrained by budget, which is relaxed by downloadable design and open access data.

In the frame of more restrictive rules, and well-defined procedures of in-house or innovation over networks, experimentation ends with the establishment of a dominant design (Henderson - Clark, 1990). Quality standards and technological requirements need to be met, and experimentation is coordinated via well-defined targets, for example to improve the characteristics of materials used, or finding solutions in the realm of ergonomics based on studies. Enterprises spend on innovation, and protect their solutions and prototypes with licenses, augmenting their transaction costs by enabling and protecting property rights and maintaining trade secrets. For innovation projects facing a less-tight means-end approach in respect of the outcome, where the aim is experimentation itself: open design table is a viable strategy. However, this implies transaction costs of aligning concepts and managing communication. In this given case those, introducing the open design table method raised coordination costs:

\begin{abstract}
"non tutti questi progettisti sono abituati a questo tipo di progettazione, alla condivisone di proprio file, per cui molti, sono stati ancora lenti a preparare il materiale, cioe il lavoro dopo e molto lungo (...) collaborare con persone esterne in questo modo rallenta le cose, pero e stato interessante, persone sono state approciate in maniera nuova." (communication manager) "not all the designers are accustomed to this type of work of sharing their own files, for that reason, many were slow in preparing their materials, so, the work took long. (...) Collaboration with outsiders in this manner slows down things, however it was interesting, people were approached in a new way." (communication manager, 2015)
\end{abstract}

Open design table unifies experts not companies, working on ideas not pre-defined technology-intensive solutions, and as the outcome is not expected to be a final product, and launching the ideas for prototyping and licensing does not imply any obligation for the company, it provides a favorable climate for experimentation. To reduce transaction costs, the purposive division of intellectual labor among the collaborators, with a centralized coordination role played by the invited moderators and experts of Valcucine created a project close to what is described as open hierarchical mode of collaboration, as openness shall not suggest flat decision-making per se (Pisano - Verganti, 2008). Lab conditions for experimentation without the strict result-constraint relieved rigorous hierarchy. The next level of decision-making was taken by the management in its ordinary manner, that of considering the produced menu of solutions ready to be prototyped or developed.

\section{Architecture of Meanings}

Modularization defines innovation (radical, incremental, modular, architectural) by how components relate 
to the structure. To explore that relationship, Henderson and Clark (1990) rely on the architecture of a product based on core design concepts. In their definition (p. 2.) the architecture of a product along with its components make up a system that makes it function. Furthermore, a component embodies a core design concept, and performs function. They point out two different types of knowledge that is required here: 1 . the knowledge of the component and the way it is implemented, 2. architectural knowledge: how components are linked together to make up a whole. Henderson and Clark illustrate that with the motor of a fan being a component of the design, with a function to deliver power to the fan. Design concepts might vary for delivering power, where one is chosen, and that is the core design concept. In this case the component (the motor) becomes the physical implementation of the given concept. Valcucine communicates a set of values that are represented in each of their product or set of products. These values can be understood as core design concepts, as they define the direction of technological and ergonomic improvements carried out through the evolution of kitchen design. Furthermore, if we consider the product as architecture of meanings, then core design concepts (referred to as values) encapsulate meanings of the product (here: beauty, functionality, ergonomics, and sustainability).

\section{Architectural and Component Knowledge}

Figure 3

\begin{tabular}{|l|l|l|}
\hline \multicolumn{1}{|c|}{$\begin{array}{c}\text { Knowledge of } \\
\text { Valcucine }\end{array}$} & \multicolumn{1}{|c|}{$\begin{array}{c}\text { Contributors' } \\
\text { Knowledge }\end{array}$} & $\begin{array}{l}\text { Product as } \\
\text { a System }\end{array}$ \\
\hline $\begin{array}{l}\text { Accumulated know- } \\
\text { ledge on the evo- } \\
\text { lution of the core } \\
\text { design concepts } \\
\text { featuring the compo- } \\
\text { nents both in physical } \\
\text { embodiment, functi- } \\
\text { on and as meanings }\end{array}$ & $\begin{array}{l}\text { knowledge related to } \\
\text { the core design con- } \\
\text { cepts of Valcucine }\end{array}$ & $\begin{array}{l}\text { Component } \\
\text { and how it } \\
\text { is imple- } \\
\text { mented }\end{array}$ \\
\hline $\begin{array}{l}\text { Accumulated know- } \\
\text { ledge on the archi- } \\
\text { tecture of previous } \\
\text { designs learned }\end{array}$ & $\begin{array}{l}\text { obtained within this } \\
\text { project on the archi- } \\
\text { tecture of a specific } \\
\text { design }\end{array}$ & $\begin{array}{l}\text { Architec- } \\
\text { ture }\end{array}$ \\
\hline $\begin{array}{l}\text { Repository know- } \\
\text { ledge (technology) at } \\
\text { the suppliers net } \\
\text { Accumulated know- } \\
\text { ledge on design and } \\
\text { technology }\end{array}$ & $\begin{array}{l}\text { Accumulated know- } \\
\text { ledge gained in col- } \\
\text { laborative innovation } \\
\text { projects on experi- } \\
\text { mentation and related } \\
\text { design methodology }\end{array}$ & Technology \\
\hline
\end{tabular}

Modeling the interaction of knowledge within the collaboration illustrates architectural innovation. The team of Valcucine obtains the knowledge of the core design concepts that feature the components, the accumulated knowledge on the evolution of these core design concepts, the way they have been implemented, and the accumulated knowledge on the architecture of previous designs learned. What the collaborating designer team added was their knowledge related to the core design concepts of Valcucine, accumulated knowledge gained in collaborative innovation projects on experimentation with related design methodology, and technological knowledge outside the scope of Valcucine's designer team (for e.g. on digital fabrication, graphic design, etc). What is learned through interaction within the project is a jointly shared and developed knowledge that targets both core concepts and architecture. (Figure 3)

Innovation in the Kitchen Becomes Open project, thus stems here rather in the sphere of stretching the meanings created, than fine-cut technological or quality improvements. Solutions developed are in the domain of exploring the core design concept of sustainable design deriving from Latouche's frames adapted by Gabriele Centazzo, without the presence of rigorous control of the usual engineering practice (Montalti, 2014). Valcucine introduced radical innovation in exploring ergonomics and sustainability in kitchen engineering during its evolution of design. The concept of sustainability for example is a core concept bridging all products and product lines of Valcucine over time, where constant improvements in design are the actual implementation of this concept, at the same time refining its meanings. Sustainability, which gains special importance in this project, unfolds as dematerialization, recycling, reduction of toxic emissions, long-lasting aesthetics and technology. The basis, the Meccanica model, served as a tentative to produce a kitchen exploring in-depth the philosophy of degrowth (products of DeMoDe brand) by the $8 \mathrm{Rs}^{6}$ inspired by Serge Latouche. Valcucine's core design concepts rhyme with those of makers' on reusability, recycling and search for sustainable solutions. Entering the world of makers the core design concepts of Valcucine gain a new shade, exploring solutions along shared values but from new approaches. The widespread argument on the movement of makers gaining power as an answer to economic crisis suggests that the driver of innovation in the case of makers is to find solutions based on achievable raw material (reused and thrifted spare parts, tools, old machinery, etc.) with low costs. This approach serves a democratic way to find solutions to needs, and reuse of available resources, and reducing resources consumed, like water, energy, gas. The solutions developed during the project reflect this approach. In real-life conditions engineering of a new product takes years within the company, as constant 
testing and fine-tuning to meet the above-mentioned requirements is a rigorous part of the project. The solutions developed as a result of 'Kitchen Becomes Open' were guided by Valcucine's designers and experts, without going through the validation channel.(Figure 4)

\section{Figure 4.}

\section{Grey Water}

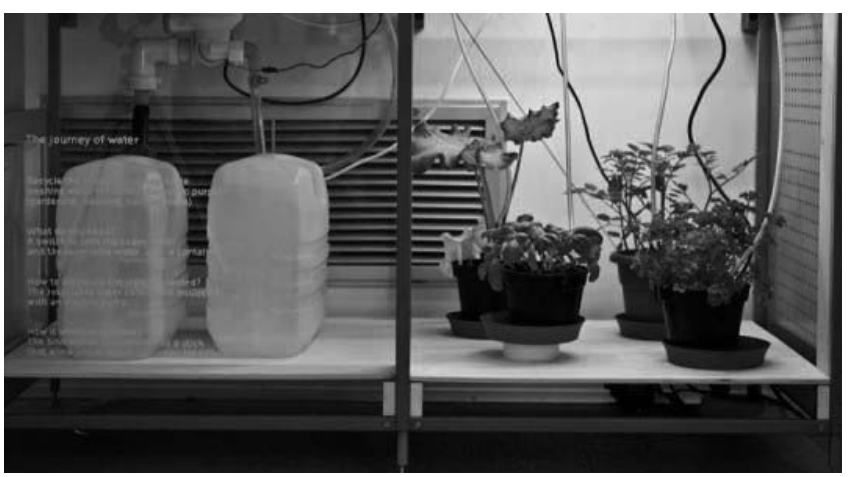

Source: www.demode/openkitchen

A solution ${ }^{7}$ explored how grey water can be reused, for e.g. that of vega-originated cooking for gardening, and cleaning. Another converted the fabric used for the cupboards of Meccanica, into shopping bags. Marina Cinciripi and Vittorio Cuculo designed an infographic with reactive and conductive LEDs tracking kitchen tools and cupboards. (Figure 5 and 6 )

\section{Open Design Table}

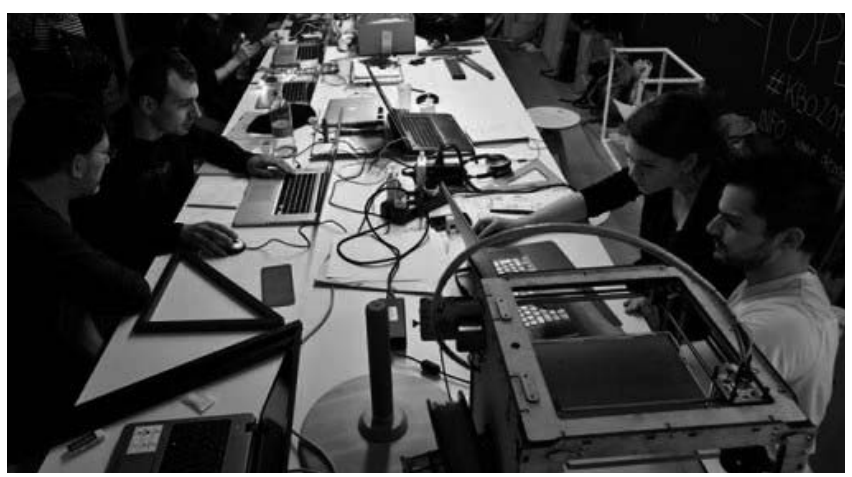

Source: http://www.domusweb.it/it/notizie/2014/04/19/cucina_open_source.html

Valcucine created a platform for entry for innovators: open access solutions are to be developed. Meccanica is a platform for makers and for food design conscious consumers willing to add modules developed by communities of digital fabrication. In sum, complementary elements are now open to other producers (for e.g. food-capable 3-D printers, laser cutters), and for single-user and collaborative innovators.
Tracking tools and cupboards

Figure 6.

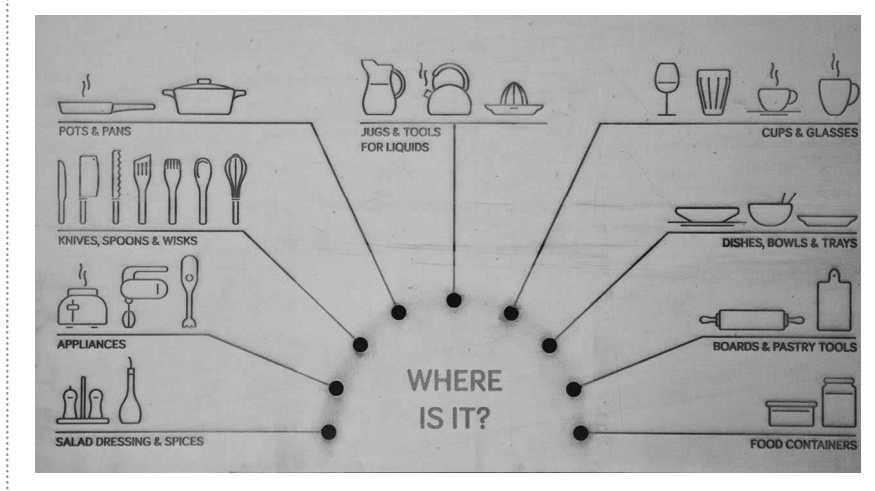

Source: http://www.domusweb.it/it/notizie/2014/04/19/cucina_open_source.html

The outcomes of the project are reusable and open for anybody to innovate on. This frees from property rights protection, and benefits the enterprise with the role of being a forerunner as paternity of the design shall be indicated. The value of innovation benefits those who will build upon the $\mathrm{CC}$ licensed prototypes, and solutions considered to be elaborated as a product under Valcucine in the future.

No matter how powerful 'Kitchen Becomes Open' was as an experiment toward opening a platform inviting single-user and collaborative innovators to contribute, the project added to the immaterial value of the brand. The project served for raising awareness of the public with media coverage about the values of Valcucine, providing a first-hand experience on how these values (sustainability, responsibility, social awareness) transform into design, backed by debates and discussions moderated by professionals.

Publicity was reached by the partners involved. Previous events organized by Valcucine during Fuori Salone also involved direct public engagement: people could bring their own laundry to be washed, dried and ironed in the showroom while launching Lavanderia (laundry) of Valcucine. Kitchen Becomes Open expanded the horizon toward sourcing in maker communities. Since, Meccanica entered the Casa Jasmina of Arduino, a lab, gallery and open space for experimentation developing a connected home.

\section{Conclusions}

Kitchen design needs to relate to current trends in food consumption and cooking patterns, where the household's kitchen has turned into a lab, and where cooking became the field for communities and service-providers to experiment in the intersection of food and design seasoned with easy-to-consume narratives of slowfood. Sustainability, eco-consciousness and originality 
became keywords just as beauty or ergonomics, or how to design one's customized nutrients. Digital fabrication has entered the playground of cooking vigorously experimenting with laser-cutters and edible 3-D prints (Faludi, 2017b). Producers relying on their innovation network might find themselves in lock-in, where experimental approach both to product development and communication strategy might open up new paths to follow and new audience to engage. The Kitchen Becomes Open project illustrated that hybrid forms of open collaborative innovation are viable outside opensource development. To understand and channel in the needs outside the innovation network of the firm into product design, Valcucine launched an experimental open design project. The findings of this analysis re- vealed that: just-in-time production creates an innovation network that is backed by modularization however, the firm might search for alternative sources of innovation outside its net. This approach allowed for modular innovation, along with refinement of the architecture of a modular product, Meccanica. 'Kitchen Becomes Open' was an important communication tool for engaging online communities, communities of makers and digital fabrication as well as the audience, the flaneur of the Fuori Salone. Rendering the outcomes as a public good contributes to a longer-term visibility of the brand, and creates a platform for innovation for other contributors.

In sum, the benefits of opening up the design and revealing the results of the innovation project contributed

\section{Stages of the 'Kitchen Becomes Open' Project}

\begin{tabular}{|c|c|c|c|c|}
\hline 2014 & & stages & & Actor \\
\hline January- & $\begin{array}{l}\text { The research and strategy behind the concept with the possible risks } \\
\text { and results if implemented, was delivered by DotDotDot. Based on } \\
\text { their previous experience 'Kitchen Becomes Open' was designed spe- } \\
\text { cifically to adapt the design table approach by an enterprise. The aim } \\
\text { was to use the already existing tools of open design in a setting where } \\
\text { engineering was internal to the firm. }\end{array}$ & $\begin{array}{l}\text { Elaboration } \\
\text { (research, stra- } \\
\text { tegy) }\end{array}$ & 1. & DotDotDot \\
\hline January- & $\begin{array}{l}\text { The concept of 'Kitchen Becomes Open' had to find its partners. It } \\
\text { was appealing due to its branding value, and as a communication tool } \\
\text { for large enterprises. Valcucine and DotDotDot look back to a history } \\
\text { of collaboration in the field of communication. Thus contacts were } \\
\text { established with marketing, technical, and design teams. The mana- } \\
\text { gement board of Valcucine has accepted the project after a series of } \\
\text { negotiations and presentations based on preliminary research on the } \\
\text { impacts of the project. It was rather the communication value that was } \\
\text { appealing to the management board. 'Kitchen Becomes Open' fit the } \\
\text { line of communication strategy and the philosophy of innovativeness } \\
\text { and sustainability of Valcucine. }\end{array}$ & $\begin{array}{l}\text { Selling (finding } \\
\text { a company to } \\
\text { implement) }\end{array}$ & 2. & DotDotDot \\
\hline March- & $\begin{array}{l}\text { Close cooperation of DotDotDot and Valcucine in recruitment of part- } \\
\text { nerships, suppliers, media coverage, and the team of designers. }\end{array}$ & $\begin{array}{l}\text { Finetuning, } \\
\text { partners call }\end{array}$ & 3. & $\begin{array}{l}\text { DotDotDot } \\
\text { Valcucine }\end{array}$ \\
\hline $\begin{array}{l}\text { April Fuori } \\
\text { Salone di } \\
\text { Milano }\end{array}$ & $\begin{array}{l}\text { The literal implementation of the seven days of engineering at the } \\
\text { design table during the design week 'Fuori Salone' in Milan, implied } \\
\text { very detailed and precise organizational work from catering and tech- } \\
\text { nical supply to moderating the process of design, and welcoming the } \\
\text { interested participants. }\end{array}$ & implementation & 4. & $\begin{array}{l}\text { Valcucine } \\
\text { Dotdotdot } \\
\text { Arduino }\end{array}$ \\
\hline April- & $\begin{array}{l}\text { The developed projects are open to all. The prototypes are licensed } \\
\text { under the Creative Commons, parts and ideas of the elaborated pro- } \\
\text { jects can be freely downloaded and used by third parties, given Valcu- } \\
\text { cine is indicated as a source. In this respect there is no direct commer- } \\
\text { cialization. However raising visibility of the outcomes, and the value } \\
\text { of the brand being a path-breaker in its approach, Valcucine indirectly } \\
\text { benefits from the results. }\end{array}$ & \begin{tabular}{|l|} 
Licensing open \\
source
\end{tabular} & 5. & Valcucine \\
\hline
\end{tabular}


largely to visibility and engagement. However, it seems that this project remained in the realm of experimentation with communication tools. Kitchen Becomes Open brought together the concepts and approach of digital fabrication, design for all and participation, stretching the limits of classic model of in-house design and development. Knowledge and approach of digital fabrication is an important experience within the technical realm of finding solutions, and furthermore it provides with a further path for understanding user experience in a new way: what would users like to fabricate, and what are the possible points of entry for users in creating their kitchen. (Figure 7)

\section{Jegyzetek}

${ }^{1}$ http://reprap.org/http://en.wikipedia.org/wiki/RepRap_Project

${ }^{2}$ Giulio Iacchetti (designer), Stefano Maffei (Politecnico di Milano), Dario Buzzini (IDEO New York), Massimo Menichinelli (open design facilitator) Enrico Bassi (FabLab Torino), Zoe Romano (Arduino)

${ }^{3}$ Daniele Caltabiano - student, Andrea De Chirico - designer, Laurence Humier - MISS DESIGN progettista, Alexander Kashin - KINK FAB designer, Cécile Leporte - ULTRA ORDINAIRE designer, Emanuele Magini designer, Marco Napoli - designer, Michele Novello - LABORTORIO GRAFFE designer Liviana Osti - designer, Francesco Rodighiero - SRA designer, Kodo Sam - developer, Juan Soriano Blanco- designer

${ }^{4}$ The applicants were ranging from 23 to 62 years old, gender ratio $39 / 61$ women/men, and from 16 countries.

${ }^{5} \mathrm{https}: / /$ creativecommons.org/licenses/by-nc-sa/4.0/deed.it

${ }^{6}$ redistribute, reuse, recycle, reduce, relocate, renovate, re-contextualize, re-evaluate

${ }^{7}$ http://kbo2014.tumblr.com/

\section{References}

Alexander, Ch. (1964): Notes on the synthesis of the Form. Boston: Harvard University Press

Arksey, H. - Knight, P. (1999): Interviewing of Social Scientists. An Introductory Resource with Examples. Thousand Oaks: Sage

Arvidsson, A. (2005): Brands. A Critical Perspective. Journal of Consumer Culture, 5/2, p. 235-258.

Baldwin, C. Y. - Clark, K. B. (2000): The Power of Modularity. Design Rules, Part I. Boston: MIT Press

Baldwin, C. Y. - von Hippel, E. (2011): Modeling a Paradigm Shift. From Producer Innovation to User and Open Collaborative Innovation. Organization Science, 22/6, p. 1399-1417.

Benkler, Y. (2006): The Wealth of Networks. How Social Production Transforms Markets and Freedom. New Haven: Yale University Press. retrieved: http:// www.benkler.org/Benkler_Wealth_Of_Networks. pdf

Bruijn, E. (2011): RepRap. The Viability of Open Design. in: van Abel et al. (2011): Open Design Now. Amsterdam: BIS Publishers (see at van Abel)
Brusoni, S. - Prencipe, A. (2001): Managing Knowledge in Loosely Coupled Networks. Exploring the Links Between Product and Knowledge Dynamics. Journal of Management Studies, 38/7, p. 1019-1035.

Brusoni, S. - Prencipe, A. (2006): Making Design Rules. A Multidomain Perspective. Organization Science, 17/2,p. 179-189. doi 10.1287/orsc. 1060.0180 Cappetta, R. - Cillo, P. - Ponti, A. (2006): Convergent Designs in Fine Fashion. An Evolutionary Model for Stylistic Innovation. Research Policy, 35, p. 1276-1290.

Caves, $R$. (2000): Creative Industries: Contracts Between Art and Commerce. Cambridge, MA: Harvard University Press

Chesbrough, H. - Teece, D. (1996): When is Virtual Virtuous. Organizing for Innovation. Harvard Business Review, 74/1, p. 65-74.

Cillo, P. - Verona, G. (2008): Search Styles in Style Searching: Exploring Innovation Strategies in Fashion Firms. Long Range Planning, 41, p. 650-671.

D'Ippolito, B. (2014): The importance of design for firms' competitiveness: a review of the literature. Technovation, vol 34, no. 11, p. 716-730., 10.1016/j.technovation.2014.01.007

Faludi, J. (2014): Fifty Shades of Innovation. From Open Toward Open Collaborative Innovation. An Overview. Budapest Management Journal, 45/11, p. 33-43.

Faludi, J. (2017a): Digital, Electronic, Visual and Audio: Digital Fabrication and Experimentation with Musical Instruments from Do-It-Yourself to New Business Models. forthcoming in KISMIF Conference Proceedings.

Faludi J. (2017b): Printing Edible Solutions. Going Beyond Chemistry and Art: Cooks as Code-Writers? Paper presented at EASA Conference 2016 at Milan Bicocca.

Franzoni, C. - Sauermann, H. (2014): Crowd Science. The Organization of Scientific Research in Open Collaborative Projects. Research Policy, 43, p. $1-20$.

Frigant, V. - Layan, J. (2009): Modular Production and the New Division of Labour Within Europe: The Perspective of French Automotive Parts Suppliers. European Urban and Regional Studies, 16/1, p. 11-25., DOI: 10.1177/0969776408098930

Garud, R. - Kumaraswamy, A. - Langlois, R. N. (eds) (2003): Managing in the Modular Age. Architectures, Networks and Organizations. Oxford: Blackwell

Gemser, G. - Wijnberg, N. M. (2002): The Economic Significance of Industrial Design Awards. A Conceptual Framework. Design Management Journal: An Academic Review, 2/1, p. 61- 71. 
Greenstein, S. (2009): Open platform development and the commercial Internet. in: Gewer A. (ed.) (2009): Platforms, Markets and Innovation. London: Edward Elgar

Henderson, R. M. - Clark, K. B. (1990): Architectural Innovation: The Reconfiguration of Existing Product Technologies and the Failure of Established Firms. Administrative Science Quarterly, Special Issue: Technology, Organizations, and Innovation, 35/1, p. 9-30.

http://dx.doi.org/10.1287/orsc.1090.0491

http://opendesignnow.org/index.php/case/unlimited-design-contest-bas-van-abel/

Jeppesen, L. B. - Lakhani K. R. (2010): Marginality and Problem-Solving Effectiveness in Broadcast Search. Organizational Science, 21/5, p. 1016-1033.

Langlois, R. N. - Garzarelli, G. (2008): Of Hackers and Hairdressers. Modularity and the Organizational Economics of Open Source Collaboration. Industry and Innovation, 15/2, p. 125-143.

Langlois, R. N. - Robertson, P. (1992): Networks and Innovation in a Modular System. Lessons from the Microcomputer and Stereo Component Industries. Research Policy, 21, p. 297-313.

Malossi, G. (2009): Phenomenology of the Fuori Salone. Lotus International, Vol. 137/March. Last revision $13 / 09 / 2014$

Malossi, G. (ed.) (1999): Volare. L'icona italiana nella cultura globale (Volare. The Icon of Italy in the Global Pop Culture), ed. Bolis, Pitti Immagine Fashion Engineering Unit

Montalti, E. (2014): Valcucine and its "Open Source" Kitchen. Design Context. Digital Review, 02.05.2014, online: http://www.designcontext.net/ en/topics/valcucine-and-its-opensource-kitchen/

Pisano, G. P. - Verganti, R. (2008): Which Kind of Collaboration is Right For You? Harvard Business Review, 86/12, p. 78-86.

Potts, J. - Hartley, J. - Banks, J. - Burgess, J. - Cobcroft, R. - Cunningham, S. - Montgomery, L. (2008): Consumer Co-creation and Situated Creativity. Industry and Innovation, 15/5, p. 459-474.
Prencipe, A. (1997): Technological Capabilities and Product Evolutionary Dynamics: A Case Study From the Aero Engine Industry. Research Policy, 25, p. 1261-1276.

Ravasi, D. - Rindova, V. (2008): Symbolic Value Creation. in: D. Barry - H. Hansen (eds) (2008): New Approaches in Management and Organization. London: SAGE, p. 270-284.

Ravasi, D. - Stigliani, I. (2012): Product Design. A Review and Research Agenda for Management Studies. International Journal of Management Reviews, 14/4, p. 464-488. DOI:10.1111/j.14682370.2012.00330.x

Schilling, M. A. (2009): Protecting or diffusing a technology platform: tradeoffs in appropriability, net-

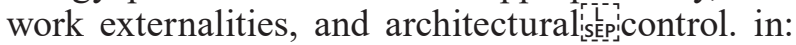
Gewer A. (ed.) (2009): Platforms, Markets and Innovation. London: Edward Elgar

Siggelkow, N. (2007): Persuasion with case studies. Academy of Management Journal, 50/1, p. 20-24.

Simon, H. (1969): The Sciences of Artificial. Boston: MIT Press

Stake, R. E. (2003): Case Studies. in: Denzin N. K. - Lincoln Y. S. (eds.) (2003): Strategies of Qualitative Inquiry. Thousand Oaks: Sage Publications, p. 134-164.

Takeishi, A. (2002): Knowledge partitioning in the inter-firm division of labor: The case of automotive product development. Organizational Science, 13/3, p. 321-338.

Tran Y. (2010): Generating Stylistic Innovation. A Process Perspective. Industry and Innovation, 17/2, p. 131-161. DOI: 10.1080/13662711003633322

van Abel, B. - Eyers, L. - Klaassen, R. - Troxler, P. (2011): Open Design Now. Amsterdam: BIS Publishers

Verganti, $R$. (2009): Design-Driven Innovation: Changing the Rules of Competition by Radically Innovating What Things Mean. Boston: Harvard Business Press

Yin, R. K. (2003): Case Study Research. Design and Methods. Third ed. Applied Social Research Methods Series Vol. 5., London: Sage Publications 